Civic Review, Vol. 16, Special Issue, 2020, 399-412, DOI: 10.24307/psz.2020.1225

László Balázs

\title{
Organisational Culture in Educational Institutions in Central, Northern, and North-Eastern Hungary
}

\section{SUMMARY}

The purpose of this research is to complement and test previous Hungarian studies about organisational culture at public educational institutions, and to provide insight into the current cultural idiosyncrasies of educational institutions. It is presumed that besides having an organisational culture with focus on rules, schools display support and innovative features in growing numbers. It is also assumed that there are significant differences between the perceptions of the management and the employees when it comes to culture. In this study, 1030 persons from 44 public institutions provided data in two cycles of data collection performed in Budapest, and in KomáromEsztergom, Fejér, Pest, Heves, Hajdú-Bihar and Nógrád counties. Results show that, besides focus on rules, there is a substantial presence of support cultural values, including important examples for innovative culture, even if in modest numbers, mostly in
Budapest and its agglomeration, i.e. in Pest, Fejér and Komárom-Esztergom counties. Besides a typological approach to organisational culture, sophisticated distinctions could be made in the findings with the help of cultural parameters. As a result, it may be argued that the number of years spent in an institution, age and gender have the most profound influence on the perceptions of organisational culture. Finally, the composition of the sample also suggests feminisation and aging in teaching.

Journal of Economic Literature (JEL) codes: D91, E71, M14

Keywords: organisational culture, cultural parameters, educational organisation

\section{INTRODUCTION}

Hungarian researchers of organisational psychology began to show interest in the study of educational organisations in the

Dr. László Balázs PhD, Associate Professor, Head of Institute of Social Sciences, University of Dunaújváros, Hungary (balazsl@uniduna.hu). 


\section{Academic Workshop}

second half of the 1990's, when Hungarian public education underwent profound changes. Previously, the central government had not analysed the strengths and weaknesses of individual institutions. With the political transition to capitalism and the re-structuring of school management, this perspective changed, and the trend accelerated with the competition triggered by the free choice of schools granted as a result of the constant decrease of student numbers. It was recognised that, just as in business, it was important to study the organisational features of educational institutions before decisions. By the 2010's, the wave of transformations had been terminated, with more or less success. Now a new, centrally governed wave of transformations began. One of the greatest changes brought about by the 2012 Act on Public Education was that, starting from 2013, every educational institution would be maintained by the state, except for kindergartens. Another significant change affected vocational education: dual training was introduced and companies were involved in the education process (Szabó, 2015). Educational organisations had to face another challenge. These changes in public education and policy, the problems of organisational restructuring, the smooth functioning of institutions that had undergone change, the policies introduced due to the COVID-19 pandemic, the shift to digital education and the economic and financial changes (Lentner and Kolozsi, 2019) all point to the necessity of studying the psychological aspects of these organisations.

Schools at the bottom tiers of the educational system are very different in spite of their formal similarities-every organisation has its own identity and its own culture. These differences were first studied system- atically by Halász, who published his results in 1980 about the analysis of the organisational climate in schools. Besides studying the environment of the organisation and the organisational climate, in the 1990's researchers focused on psychological concepts, which further emphasised the perceptibility of organisational idiosyncrasies. Mészáros (2002) edited a review volume, which gave insight into the general and social psychological world of schools. This volume approaches social psychological concepts through a theoretical and abductive approach, emphasizing organisational psychological interpretations (Barlainé, 2002; Bagdy, 2002; Serfôző, 2002). Organisational psychologists also started to show interest in the internal operation of schools. The study of educational organisations became a key field, and empirical studies were published with focus on schools' organisational culture (Szabolcsi, 1996; Kovács, 1996; Baráth, 1998; Kovács et al., 2005; Serfőzô, 2002; 2005; Balázs, 2014; 2015; 2020).

The study of the various relationships, developments and possible changes in the organisational culture, and the definition of its methodology enable the promotion of results at the workplace and the establishment of a positive workplace atmosphere, and contributes to the success of education. At the turn of the millennia, several Hungarian researchers devoted their attention to the characteristic features of organisational culture at schools; but by now, interest has decreased again, and the focus of studies in educational institutions has shifted. In this study, an exhaustive analysis is given of educational organisational culture through the organisational cultures of 26 institutions, with the help of the framework of "competing values", set up by Quinn and Rohrbaugh (1983), by Robbins's model 


\section{Academic Workshop}

(1993) complemented by that of Bakacsi (1996). The purpose of this analysis is to update data about educational organisational culture, and to further articulate organisational culture types in education with the help of various parameters in organisational culture, including the idiosyncrasies of organisational members. Note that the organisational culture of schools changes and transforms together with broader social changes.

\section{THEORETICAL BACKGROUND}

Educational institutions are unique and different. Due to the competition for students, schools need to become more conscious of the internal and external processes, and of the image of the institution. The concept of organisational culture emphasises precisely this institutional uniqueness. The study of organisational culture is also important from a pedagogical point of view, as institutional values may strengthen or weaken educational objectives and learning outcomes.

Besides identifying characteristic school culture types, the studies show a correlation between organisational culture, the size and performance of the organisation, and the satisfaction and commitment of its members. Below are descriptions of the models used in Hungarian research, and the results that demonstrate the idiosyncrasies of schools' organisational culture in Hungary.

Quinn and Rohrbaugh's (1983) “competing models" framework may be generally used for the research of the performance criteria of organisations. Organisations rely on certain values to enhance their efficiency and performance. The model defines a three-dimensional organisational framework for an efficient organisation:
1. Focus of an organisation may be internal (person focus) or external (organisation focus),

2. An organisational culture may prefer stability and/or flexibility,

3 . While achieving the desired goals, focus may be placed on the means of achievement or on the target.

The first two parameters describe the four basic types regarding the efficiency of organisational culture, while the third one identifies the tool- or goal-oriented approach constituting a subset of the latter (Table 1). Quinn placed these four types on two axes: control and internal/external focus; and as a result, he was able to identify the following organisational culture types.

In a rule culture, there are well-defined roles. The basic expectation is to follow the rules. It is important to respect formal positions. This model is characterised by a high level of internal focus and controlling, and it results in order, predictability, stability and balance. Two important processes belong here: documentation and stabilisation. Thus, the leader's two primary duties are observation and coordination. Since he is a monitor, he knows what happens in the organisation and as a coordinator, he is expected to maintain the structure and ensure the operation of the whole organisation.

In contrast, in an innovative culture, focus is on creativity and risk assumption. It is characterised by free information flow, teamwork and continuous learning by the members, who are not controlled but are encouraged and inspired. Outward orientation and control are marginal. Its main strengths are adaptation skills and an ability to change. The leader's two main roles are that of an innovator and a broker. As an innovator, the leader is supposed to recognise 


\section{Academic Workshop}

and promote necessary changes. As a broker, he is to maintain external legitimacy.

In a goal-oriented culture, focus is on profit, productivity and efficiency. Such an organisation stresses the clarification of tasks and the definition of targets. It is characterised by a high level of control and outward orientation. It is led by effectiveness, control and instructions. The leader's two primary roles are that of a director and a producer. As a director, the leader formulates expectations, while as a producer, he focuses on the tasks and on work, enquires about the employees and motivates them.

In contrast, a support culture focuses on accord, cohesion, the role and importance of teamwork, and internal control. In this culture, focus is on human resources, the possible individual development and commitment. This organisational culture monitors internal processes and is flexible at the same time. The leader's two primary roles are that of a facilitator and a mentor. As a facilitator, he is expected to promote joint efforts, while as a mentor, he is supposed to develop abilities and skills, to provide for training opportunities, and to help employees plan their personal development.

Besides Quinn's Competing Values Framework, Handy's approach to organisational culture has also been used in numerous research projects. It is also a typological approach, which classifies types in terms of leadership roles, attitude to the environment, direction, the manner of decisionmaking and organisational performance. Handy distinguishes four types. A power culture is characterised by centralised power, with a leader controlling the organisation from a centre. Every process starts and ends in the centre. Empathy, tolerance and trust are important values in this culture. A role culture may be likened to the structure of a Greek temple, and its leadership to Apollo. The pillars represent well-prepared, functional units, whose operations are defined

Figure 1: Quinn's Competing Values Framework (based on Quinn and Rohrbaugh, 1983).

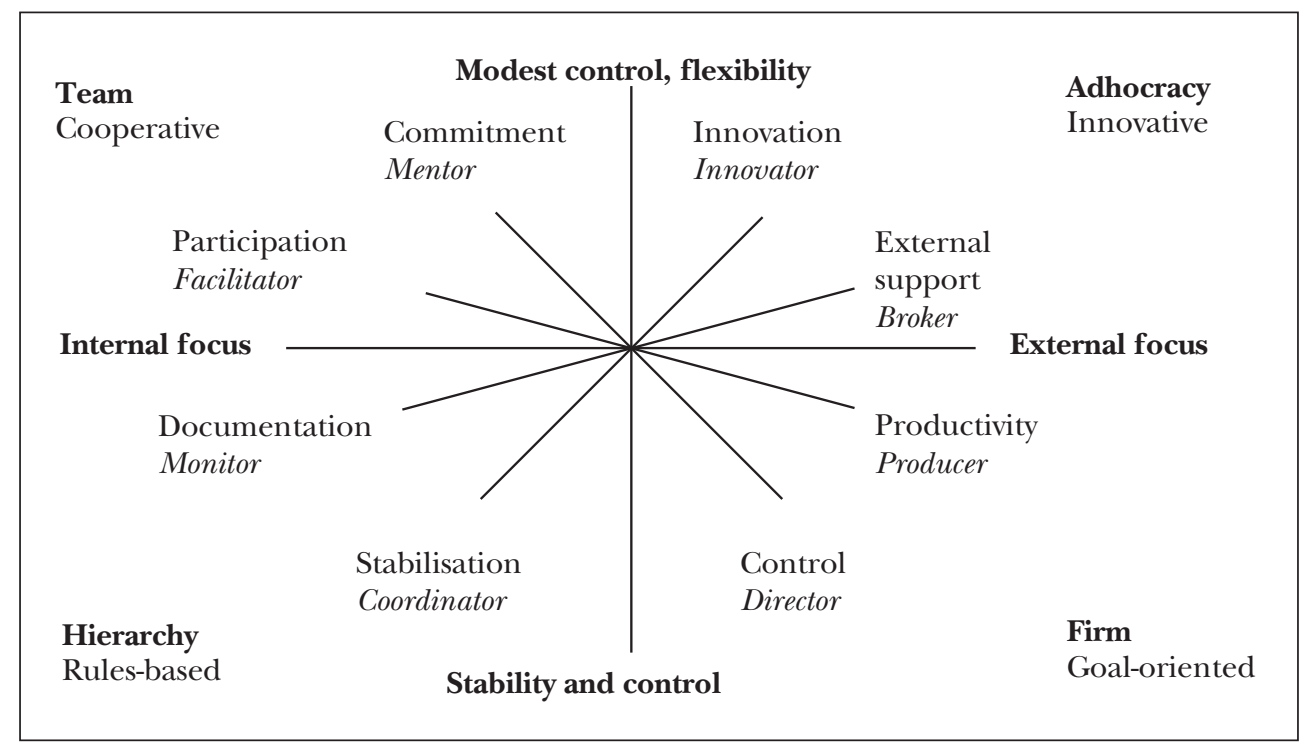

Source: Author's own elaboration 


\section{Academic Workshop}

by competencies, regulations, and rules. Well-defined roles are more important than persons, and power comes from the position in a hierarchy. The structure of a task culture is like a network. The leader in this culture may be likened to Pallas Athene. A lot of emphasis is put on the resources that are necessary for the completion of tasks, and for the selection of workers who work in teams. Finally, a person culture may be illustrated by a loose volume of dots. The individual is in the focus here. Handy attributes the personality traits of Dionysus to this organisational culture. This kind of culture emerges when highly qualified, creative people join forces to accomplish innovative tasks by collectively drawing from certain resources (Handy and Aitken, 1986).

Quinn, on the other hand, developed his framework on the basis of the characteristic features of organisations that operate efficiently. The difference of his model from Handy's is reflected by the name "competing values framework," which carries the assumption that organisations aim to increase their efficiency and performance by concentrating on different values.

Using Handy's culture model in his 1996 work, Szabolcsi concluded that bigger vocational schools and highly structured schools are characterised by a task culture, while the role culture predominates in elementary education and smaller institutions of secondary education. Therefore, a correlation between the size of the institution and its organisational culture is detectable: size dominantly affects organisational culture. According to Kovács (1996), educational organisations are characterised by a high level of stability, and a desire for equilibrium. Innovation and team spirit are low, and care for human relationships and conflicts are missing from schools. In his re- search, he applied Quinn's model. Serfőzó (2005) obtained similar results. He found that - besides the personal impact of the leader -, school size was one of the causes for the differences in culture. Municipal schools were most of all characterised by focus on rules, while private schools were characterised by innovation. Both school types were characterised by the absence of focus on goals.

According to Baráth (1998), teachers typically view their own institution as goaloriented, while focus on rules was secondary. He found that teachers had a different concept of the organisation than directors. As an explanation for the differences, he argues that, from the perspective of leadership, there exists a more complex image of the institution, while teachers typically have a more static vision. Another of his conclusions refers to the applied methodology. His findings show that Quinn's Competing Values Framework may also apply to schools.

Serfőzô (2005) a conducted more exhaustive survey of 28 schools between 1996 and 2001 to explore the organisational culture of educational institutions. He defined five factors to characterise schools: trust, focus on performance, team spirit, innovation and development, control and organisation. In his interpretation, these factors correspond to the types set in the Competing Values Framework, but a new factor emerges in schools with regards to the style of management: trust. His findings show that traditionally, schools are authoritarian, formalised, and well-regulated institutions. Externally, however, they follow the norms of cooperation and support. Therefore, the two strongly correlating culture types are of the rule and support cultures.

Kovács and his colleagues (2005) examined the organisational culture of schools 


\section{Academic Workshop}

and aimed to further articulate Quinn's culture typology. The starting point is the set of cultural parameters developed by Robbins (1993; Kovács et al., 2005) and based on the characteristic features that determine the members' feelings about organisational culture.

Organisations are characterised by the following key parameters:

1. Identification with the job or with the organisation: The two extremes of this parameter include identification with the entire organisation and with certain working groups or with a job.

2. Focus on an individual or on a group: Individual or group targets are more emphatic. Person focus is more characterised by the promotion of freedom, independence and responsibility, while in the event of a group focus, the emphasis is on group targets.

3. Focus on the individual: Task or relationship-oriented leadership, which characterises the leader-employee relationship. To what extent do leaders consider the impact of the solution to organisational tasks on people?

4. Internal dependence or independence: It relates to the level of integration and determines the independence of organisational units and the extent of central coordination and centralisation.

5. Strong or weak control: It relates to the level of regulation and to the direct supervision of control over the employees.

6. Risk taking or risk avoidance: It relates to tolerance regarding uncertainty in the organisation. How much risk taking and innovation is expected or supported, and how much uncertainty is tolerated?

7. Performance orientation: It is characteristic of the system of awards. To what extent is the system of awards built on per- formance and to what extent does it take other factors into account?

8. Conflict tolerance: It characterises the leadership and the organisation by the toleration or encouragement of the open expression of dissenting views.

9. Goal or means orientation: It is characteristic of the leadership based on a focus on organisational results or the process of achieving the targets.

10. Open or closed system: It is characteristic of the relationship between the organisation and its environment. This aspect presents the organisation's responsiveness to external changes.

11. Short- or long-term thinking: It reflects the organisation's future planning.

It was found that schools were typically predominated by a rule culture, although in some institutions the support and the goal-oriented culture were present in a marked way. Within the individual culture types, the researchers have distinguished the factors that determine the cultural features of a given institution, and identified three key parameters:

1. Teacher (person) versus school (organisation) focus,

2. Innovation (uncertainty-toleration) versus value- (security-) orientation,

3. Leadership characterised by strong versus weak control.

As a result of the study, it was possible to further sophisticate the description of the specific culture types along the three parameters.

\section{Research objectives}

AND METHODOLOGY

The objective of this research is to complement and test research on organisational culture in schools in Hungary, and to pro- 


\section{Academic Workshop}

vide an exhaustive insight into the cultural features of public educational institutions. It is assumed that the findings of previous studies continue to be valid, but

changes can be detected in the key culture types. Besides focus on rules, schools now display features of support and innovative cultures.

Two questionnaires were used for the analysis of organisational culture. Quinn's Competing Values Framework, as elaborated by Quinn and Rohrbaugh (1983) was sed to define the type of culture of the studied institutions. This questionnaire was used because Baráth (1998) found that it was relevant in a school environment.

This questionnaire includes six groups of questions about the following:

- character and basic type of the organisation,

- cohesive force of the organisation,

- leader of the unit,

- atmosphere in the organisation,

- evaluation of success,

- the leadership system.

Within each group of questions, there are four statements reflecting features of each culture. It is the task of the respondents to score statements according to how true they are for their own institutions. In each question, 100 scores can be distributed between the four answers. Values relating to each culture type can be derived from the average value of the scores of the related answers.

The further articulation of organisational culture was enabled by Robbins' 11 culture parameters (1993), which depart from the characteristic features that define members' feelings about the organisational culture. On the basis of the theoretical model, the questionnaire developed by Zoltán Kovács enables the characterisation of organi- sations by 22 pairs of values. Two statements are related to each parameter. Respondents rank any given culture on a scale of 1 to 7 based on the extent to which they find the statement true about their organisational culture. Thus, the predominance of particular values is established by the number. The final score for a $\mathrm{n}$ organisation is obtained by averaging the statements about particular values. Table 1 shows the results of value pairs.

During these calculations, an SPSS correlation calculation, an ANOVA analysis, and an independent samples T-test were performed.

\section{SAMPLE}

Data were collected in two phases: 25 institutions were surveyed between 2010 and 2013, and another 19 between 2014 and 2019. In the first survey, 17 elementary schools, 7 secondary schools, and one combined elementary and secondary school were surveyed, and 589 questionnaires were completed. These institutions are located in Budapest, Komárom-Esztergom, Fejér, Pest, Heves and Hajdú-Bihar and Nógrád counties, in the central, northern, and north eastern regions of Hungary. Gender distribution shows feminisation in the teaching profession: 14.5 per cent men (85 persons) and 78.4 per cent women (460 persons) filled out the questionnaire. In terms of age, the distribution is no surprise: about 38 per cent (223 persons) were older than 48 , 30 per cent (177) were between 39 and 47 , and only 25 per cent ( 145 persons) were younger than 38 years old. 7 per cent of the respondents did not answer the question relating to age.

In the second phase of the survey, an additional 14 elementary schools and 5 second- 


\section{Academic Workshop}

Table 1: The scoring of value parameters

\begin{tabular}{l|l|r|r}
\hline Internal dependence & 1 & 7 & Independence \\
\hline Goal focus & 1 & 7 & Means focus \\
\hline Person focus & 1 & 7 & Group focus \\
\hline Strong control & 1 & 7 & Weak control \\
\hline Relationship focus & 1 & 7 & Task focus \\
\hline Risk-taking & 1 & 7 & Risk avoidance \\
\hline Conflict tolerance & 1 & 7 & Conflict avoidance \\
\hline Short term time focus & 1 & 7 & Long term time focus \\
\hline Identification with the institution & 1 & 7 & Identification with the position \\
\hline Performance focus & 1 & 7 & Other \\
\hline Closed system & 1 & 7 & Open system \\
\hline
\end{tabular}

Source: Author's own work

ary schools, located Budapest, KomáromEsztergom, Fejér, Pest and Heves counties, were added to the sample. 460 questionnaires were completed. The gender distribution slightly differed from the previous phase, which may be explained by the fact that in this phase, the number of vocational schools was higher: 34 per cent (157 persons) of the respondents were male, and 66 per cent (313) were female. In terms of age, this sample did not show any major difference: 52 per cent (238 persons) of respondents were older than 48,30 per cent (136 persons) were between 39 and 47, while only 18 per cent ( 86 persons) were younger than 38 .

The data were analysed in two steps:

First, the characteristics of the organisational culture were identified and then the culture was modulated: on the basis of data, the aimed was to identify the significant features of given culture types with the help of ANOVA, T-test and correlation analysis.

The comparison between the results of previous research data and the data of the two samples are presented in order to identify potential changes in culture.

\section{FINDINGS}

Identification of the characteristic features of organisational culture

Table 2 shows the distribution of organisational culture types across schools relative to the complete sample. Based on the members' perception of the primary characteristic features, 15 support, 8 innovative, 20 rule, and 1 goal-oriented cultures were identified. The ANOVA analysis and a T-test were used to capture the differences between culture types along Robbins' criteria.

The results of the ANOVA analysis show a significant difference $(p<0,05)$ between the surveyed three culture types in more than one variables:

- identification with the organisation/job,

- relationship/ask focus,

- internal dependence/independence,

- strong control/weak control,

- risk-taking/risk-avoidance,

- performance criteria/other criteria,

- conflict tolerance/ conflict avoidance,

- goal focus/ means focus,

- short-/long-term planning. 


\section{Academic Workshop}

Table 2: Value parameter scores (grey: key culture type)

\begin{tabular}{|c|c|c|c|c|c|}
\hline & $\mathbf{N}$ & Support & Innovative & Rule & Goal-oriented \\
\hline 1. & 43 & 24.25 & 34.26 & 20.44 & 20.90 \\
\hline 2. & 15 & 49.78 & 16.06 & 24.17 & 8.67 \\
\hline 3. & 35 & 23.55 & 30.96 & 23.31 & 22.08 \\
\hline 4. & 13 & 21.47 & 20.19 & 43.76 & 14.58 \\
\hline 5. & 25 & 18.66 & 17.54 & 43.84 & 20.18 \\
\hline 6. & 34 & 30.95 & 24.26 & 26.38 & 17.90 \\
\hline 7. & 7 & 55.24 & 18.33 & 22.02 & 4.40 \\
\hline 8. & 12 & 29.35 & 18.86 & 37.50 & 14.09 \\
\hline 9. & 13 & 15.47 & 26.49 & 38.82 & 16.82 \\
\hline 10. & 44 & 22.20 & 24.73 & 28.53 & 24.15 \\
\hline 11. & 32 & 34.62 & 24.95 & 31.77 & 8.82 \\
\hline 12. & 18 & 24.80 & 21.08 & 38.33 & 15.69 \\
\hline 13. & 17 & 35.93 & 20.15 & 29.46 & 14.66 \\
\hline 14. & 8 & 45.21 & 23.54 & 20.52 & 11.15 \\
\hline 15. & 16 & 52.92 & 19.11 & 22.81 & 6.09 \\
\hline 16. & 17 & 29.12 & 17.60 & 34.90 & 17.89 \\
\hline 17. & 30 & 13.72 & 24.11 & 37.75 & 24.34 \\
\hline 18. & 23 & 29.67 & 27.50 & 26.80 & 16.03 \\
\hline 19. & 36 & 35.53 & 17.63 & 34.96 & 11.59 \\
\hline 20. & 46 & 26.36 & 11.80 & 49.60 & 12.24 \\
\hline 21. & 25 & 35.76 & 22.22 & 30.76 & 10.97 \\
\hline 22. & 12 & 27.25 & 21.08 & 35.83 & 15.83 \\
\hline 23. & 13 & 26.31 & 21.71 & 35.76 & 16.36 \\
\hline 24. & 11 & 16.59 & 17.65 & 41.14 & 24.62 \\
\hline 25. & 25 & 29.34 & 26.84 & 32.33 & 12.12 \\
\hline 26. & 23 & 19.38 & 25.36 & 33.15 & 22.19 \\
\hline 27. & 10 & 26.38 & 20.33 & 29.68 & 23.21 \\
\hline 28. & 42 & 29.35 & 27.61 & 23.63 & 20.06 \\
\hline 29. & 31 & 26.30 & 23.52 & 30.20 & 21.00 \\
\hline 30. & 11 & 24.45 & 25.37 & 28.19 & 22.76 \\
\hline 31. & 24 & 24.77 & 27.95 & 25.91 & 22.56 \\
\hline 32. & 18 & 28.89 & 25.56 & 26.11 & 18.33 \\
\hline 33. & 17 & 25.59 & 27.06 & 23.35 & 22.53 \\
\hline 34. & 15 & 23.93 & 27.86 & 24.64 & 25.00 \\
\hline 35. & 26 & 30.19 & 21.15 & 25.96 & 22.69 \\
\hline 36. & 45 & 27.11 & 22.91 & 28.57 & 21.64 \\
\hline 37. & 13 & 41.75 & 19.92 & 22.17 & 17.00 \\
\hline 38. & 14 & 27.89 & 26.95 & 22.16 & 22.56 \\
\hline 39. & 28 & 25.02 & 29.18 & 22.48 & 23.74 \\
\hline 40. & 25 & 26.73 & 23.17 & 29.02 & 20.54 \\
\hline 41. & 44 & 28.16 & 38.45 & 18.52 & 15.00 \\
\hline 42. & 20 & 27.89 & 28.16 & 25.36 & 22.37 \\
\hline 43. & 39 & 25.02 & 22.48 & 29.18 & 23.74 \\
\hline \multirow[t]{2}{*}{44.} & 15 & 26.86 & 19.99 & 24.38 & 28.67 \\
\hline & 1030 persons & 15 & 8 & 20 & 1 \\
\hline
\end{tabular}

Source: Author's own work 


\section{Academic Workshop}

On the basis of the analysis, the following conclusions may be drawn:

- Innovative culture is characterised by and differs significantly from the other two cultures -identification with the organisation, task focus, evaluation based on other criteria, goal focus, and short-term planning.

- A support culture features relationship focus, conflict tolerance, and means focus in the most marked way.

- A rule culture is characterised by a relationship focus, heavy control, risk-avoidance, and means focus, and so it is ranked between the previous two culture types.

- A goal-oriented culture is distinguished by emphatic focus on goals and risk-taking. Note that s these findings are based on data from a single institution, no definitive conclusions may be drawn.

Besides the typological interpretation of culture and its sophistication, it was also examined whether there was any similarity between the organisational cultures of schools. This analysis was based on the organisational culture parameters. Results show that there are culture parameters which, despite differing degrees of perception, show a kind of orientation in the case of schools. They are the following:

- The majority of the schools (79\%) exhibit identification with the job and the team as opposed to identification with the organisation.

- Members typically perceive organisations as person focus, they see the culture as having an emphasis on personal goals. They are characterised by independence and support to responsibility.

- This is accompanied by generally perceived $(81 \%)$ tight regulation and direct control of employees.
- In the majority of schools, members perceive the culture as risk-taking (68\%) and conflict tolerant $(70 \%)$.

- As opposed to performance criteria, these schools established other criteria $(83 \%)$ in rewarding employees.

- In the completion of goals, means focus is more predominant $(85 \%)$ than goals focus.

- In 92 per cent of these schools, the openness of the organisation and its ability to react to changes also surfaced, as opposed to closed systems.

Besides the analysis of similarities and culture types, I also found it interesting to detect correlations between the individual characteristics and the perception of the organisational culture.

- The findings show correspondence between the number of years spent in an institution, and the perception of its organisational culture. Teachers who have been in the institution for a longer time perceive their institution as less goal-oriented.

- At the same time, the same teachers are more likely to perceive the closedness of the organisation and short term focus, than their colleagues who have spent less time there.

These two statements also correlate with the results based on age:

- Older teachers are significantly more characterised by the perception of a risktaking, conflict tolerant and closed organisational culture.

- With the advancement of age, identification with the job also becomes more prominent.

Regarding the perception of culture according to gender, the following conclusions arise:

- Men are significantly more likely to perceive risk-avoidance in an organisation- 


\section{Academic Workshop}

al culture, while women are more likely to perceive their organisation as risk-taking.

Interesting findings were obtained about the perception of organisational culture on the basis of position. Respondents were classified in three groups: 1) director and vice-director, 2) group leader and 3) teacher. The findings show significant differences in six of the eleven organisational culture parameters.

- Person focus: according to the teachers' perception, leaders pays less attention to already existing relationships and tends to focus on tasks. However, directors (including group leaders) tend to perceive their organisational culture as more relationship-oriented.

- Risk-taking/risk-avoidance: directors and vice-directors perceive their organisation as significantly more innovative and risk-taking than their teachers. Teachers typically perceive their organisational culture as risk-avoiding.

- Performance focus: directors more significantly perceive the rewarding system as based on performance than teachers, who rather perceive rewarding on the basis of other criteria.

- Conflict tolerance: while directors typically perceive their organisations as more conflict tolerant, teachers significantly perceive conflict-avoidance.

- Goal focus: leaders perceive means focus more when it comes to achieving institutional objectives, while teachers typically perceive their institutions as goal-oriented.

- Closed system: directors and teachers differ in their perception of the openness of their institutions. Leaders and teachers both perceive their institutions as open, but leaders do so more markedly.

In order to interpret this data, it must be added that in the case of significant differ- ences, teachers and directors stand on the extreme ends of the spectrum, while group leaders are in the middle. A joint analysis of the two sets of data moderately changes the first set, while it is obvious that there is significant difference in the ratio of identified organisational culture types.

\section{Changes in schools' organisational culture}

Changes in schools' organisational culture were analysed along two variables. First, the aim was to find significant differences between the cultural characteristics in the specific counties, and then attempts were made at the identification of significant differences between the samples, whether it be the frequency of the presence of an organisational culture, or the articulated differences between certain culture types.

No significant difference was found between the counties where data was collected, while on the basis of frequency, institutions with an innovative culture were typically identified in Budapest and its agglomeration, i.e. in Pest, Fejér and Komárom counties.

Our results, however, demonstrate a clear difference: in the second sample, the ratio of identified organisational culture types changed. While in the first sampling phase (2010-2013), 40 per cent of the institutions had a support, 8 per cent by an innovative, and 52 per cent by a rule culture, by the second phase of sampling (20142019), the ratio of innovative institutions had increased considerably $(32 \%)$, and the number of support $(26 \%)$ and rule $(37 \%)$ cultures decreased. While during the first survey not a single goal-oriented organisational culture was identified in 25 institutions, one was found in the second sample. It is important to note that various educa- 


\section{Academic Workshop}

tional institutions were sought during the two samplings, which means that the differences identified above could be a matter of coincidence; however, previous studies show that the Hungarian educational system had been primarily characterised by a rule culture in the first place and a support culture in the second (Kovács et al., 2005; Serfőző, 2005; Balázs, 2014; 2015). In comparison, the sample taken between 2014 and 2019 shows that the innovative culture type is increasingly frequent in public educational institutions.

\section{CONCLUDING REMARKS}

The two surveys presented above have proved my assumptions. Public educational institutions used to be organised predominantly according to the rule and the support cultures. As a result of social changes, the features of the innovative culture are appearing at an increasing number of schools. Over the past five years, an example has even been found for the goal-oriented organisational culture. In addition to the typological approach to organisational cultures, culture parameters also enable further refinements in conclusion. Based on the results of previous studies, one may argue that there is a difference between the perception of culture by school leaders and school teachers.

The findings confirm the conclusions of Serfốzô (2002) and Kovács et al. (2005), and run counter the findings of Baráth (1998), who claimed that the goal-oriented culture is the most dominant one in Hungarian public educational institutions. In a subsequent work, Serfőzó (2005) describes schools through two culture types that are strongly correlated: the rule and the support culture. The findings obtained by this analysis confirm a close correlation between the two culture types.

The analyses of gender and age distribution brought about similarly interesting results. The number of years spent in the institution, age and gender all influence the perceptions of organisational culture. The composition of the samples also suggests aging and feminisation in the teaching profession, as other researchers have also indicated in their studies of the teaching career (Bacsa-Bán, 2019).

A comparison of the samples reveals that educational institutions, as organisations sensitive to the social environment, keep pace with changes and aim to respond to new developments. Compared to the sample collected at the beginning of the 2000s, the sample from 2014-2019 shows a greater number of institutions with innovative culture.

Development in the organisational culture is influenced by the foundation of the organisation, its history, and its internal and external (organisation-specific) factors. The external factors include several things that may influence the beliefs and values of the members of the organisation, such as the natural, the social and the economic environment, the history of the region, the national culture, and the legal and political circumstances. Further interesting correlations can also be detected in relation to cultural matters regarding the organisations' relocation and the regional host culture (Kókuti, 2011). Although a deeper analysis of the correlations between the organisational culture and the social and economic features of a region, the innovative culture could clearly be identified in Budapest and its agglomeration, i.e. in Pest, Fejér and Komárom-Esztergom counties. Such local aspects of culture types 


\section{Academic Workshop}

suggest differences in the studied areas. As the institutions that constitute the samples are located in different economic and social environments, and the latter is well demonstrated by GDP per capita. A reason for the perception of the innovative culture might include faster economic development in these regions. On the basis of the county distribution of GDP, it may be claimed that among the regions explored, Budapest, Komárom-Esztergom, Fejér and Pest county are among the most developed regions of the country (Figure 2 shows data for 2018).
As a conclusion, the cultural features of organisations constantly evolve in response to the demands of their environment. The organisational climate is also greatly affected by the responsible conduct of activities that relates to the satisfaction of the individual stakeholders (András et al., 2013). The identification and presentation of schools' organisational culture may provide an impetus to the processes that support and shift the organisation towards a goal-oriented culture in, for example, towards online and digital learning, and other economic developments.

Figure 2: GDP by county in Hungary, 2018

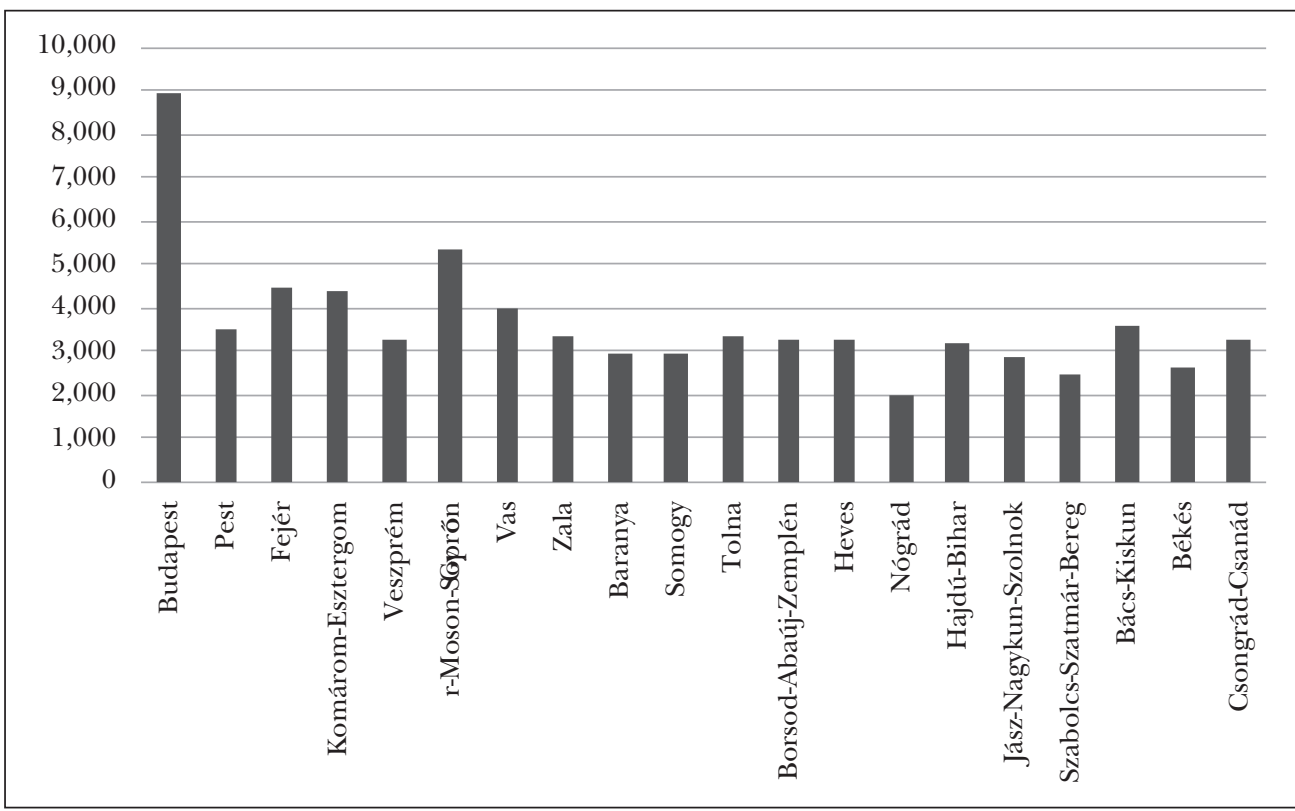

Source: Author's own work, based on www.ksh.hu/docs/hun/xstadat/xstadat_eves/i_qpt014b.html.

\section{REFERENCES}

András, I.; Rajcsányi-Molnár, M. and Füredi, G. (2013): A vállalatilag felelốs vállalat: A CSR- és a cafeteriametszet értelmezési lehetôségei a gyakorlatban [Firms with corporate responsibility: The practical levels of interpretation in the intersection of CSR and cafeteria] In: RajcsányiMolnár M. and András, I. (eds.): Metamorfózis. Glokális dilemmák három tételben [Metamorphosis. Glocal dilemmas in three propositions]. Új Mandátum Kiadó, Budapest, 127-139.

Bacsa-Bán, A. (2019): A szakmai pedagógusok (pedagógusi) pálya elhagyásának vizsgálata több 


\section{Academic Workshop}

dimenzióban [A multi-dimensional analysis of professional teachers' leaving the teaching profession]. Opus et Educatio, Vol. 6, No. 2, 257-269, http://dx.doi.org/10.3311/ope.312.

Bagdy, E. (2002): Pedagógusok mentálhigiénés multiplikátorképzése. Egy iskola mentálhigiénés továbbképzési modell alkalmazási tapasztalatai [Teachers' mental health multiplicator training: Lessons from a school's application of a mental health model]. Mészáros, A. (ed.): Az iskola szociálpszichológiai jelenségvilága [The social psychology of schools]. ELTE Eötvös Kiadó, Budapest.

Bakacsi, Gy. (1996): Szervezeti magatartás és vezetés [Organisational behaviour and leadership]. Közgazdasági és Jogi Tankönyvkiadó, Budapest.

Balázs, L. (2014): Érzelmi intelligencia a szervezetben és a képzésben [Emotional intelligence in organisations and education]. Z-Press Kiadó, Miskolc.

Balázs, L. (2015): Organisational Culture and Emotional Intelligence in School. LAP Lambert Academic Publishing, Saarbrücken.

Balázs, L. (2020): Az érzelmi intelligencia vizsgálata a szervezeti kultúra tükrében. Kutatási beszámoló [Emotional intelligence in organisational culture. Research report]. Polgári Szemle, Vol. 16, No. 1-3, 187-204, http://doi.org/10.24307/ psz.2020.0712.

Baráth, T. (1998): Hatékonyságmodellek a közoktatásban [Efficiency models in public education]. www.staff.u-szeged.hu/ barath/tanulm/BESZV. htm.

Barlainé, B. K. (2002): Szervezetfejlesztés a Bárczi Géza utcai Általános Iskola 20 éves történetében [Organisation development in the twenty years of Bárczi Géza elementary school]. In: Mészáros, A. (ed.): Az iskola szociálpszichológiai jelenségvilága [The social psychology of schools]. ELTE Eötvös Kiadó, Budapest.

Bíró, B. and Serfốzô, M. (2003) Szervezetek és kultúra [Organisations and culture]. In: Hunyady, Gy. and Székely, M. (eds.): Gazdaságpszichológia [Economic psychology]. Osiris Kiadó, Budapest.

Halász, G. (1980): Az iskolai szervezet elemzése. Kutatási beszámoló az iskolai szervezeti klíma vizsgálatáról [The analysis of educational organisations. Research report about the study of schools' organisational climate]. MTA, Budapest.

Handy, C. B. and Aitken, R. (1986): Understanding Schools as Organisations. Penguin, London.

Kovács, J. (1996): Vezetôk és menedzserek a közoktatásban - avagy vezetôi szerepfelfogások és szervezeti kultúrák [Leaders and managers in public education. Leadership roles and organisational cultures]. Magyar Pszichológiai Társaság Nagygyúlése, ELTE, Budapest.

Kovács, Z.; Perjés I. and Sass J. (2005): Iskolák szervezeti kultúrája [The organisational culture of schools]. In: Faragó K. and Kovács Z. (eds.): Szervezeti látleletek [Organisational diagnoses]. Akadémiai Kiadó, Budapest, 51-64.

Kôkuti, T. (2011): Vállalatok kultúrája vs. régiók kultúrája, hatások és kölcsönhatások [The corporate culture vs. regions culture, effects and interactions]. In: Kukorelli, K. (ed.): A tartalom és forma harmóniájának kommunikációja [Communication of harmony between content and form]. Dunaújvárosi Főiskola, Dunaújváros.

Lentner, Cs. and Kolozsi, P. P. (2019): Old Problems in a New Context - Excerpts from the New Ways of Thinking in Economics after the Global Financial Crisis. Economics E̋ Working Capital, No. $1-2,53-62$.

Mészáros, A. (2002) (ed.): Az iskola szociálpszichológiai jelenségvilága [The social psychology of schools]. ELTE Eötvös Kiadó, Budapest.

Quinn, R. E. and Rohrbaugh, J. (1983) A Spatial Model of Effectiveness Criteria: Towards a Competing Values Approach to Organisational Analysis. Management Science, Vol. 29, No. 3, 363-377.

Robbins, S. P. (1993): Organisational Behavior. Prentice-Hall, Englewood Cliffs.

Serfôzô, M. (2002) A szervezeti kultúra fogalmának, modelljeinek értelmezése az óvodában, iskolában [The theories and models of organisational culture at kindergarten and school]. In: Mészáros, A. (ed.): Az iskola szociálpszichológiai jelenségvilága [The social psychology of schools]. ELTE Eötvös Kiadó, Budapest, 381-397.

Serfôző, M. (2005): Az iskolák szervezeti kultúrája [The organisational culture of schools]. Iskolakultúra, Vol. 15, No. 10, 70-83.

Szabó, Cs. M. (2015): Lehetôségek vagy problémák? Milyen változásokat követel meg szakképzô intézményektôl a szakképzési törvény? [Opportunities or problems? The changes required of vocational educational institutions by the act on vocational training]. Szak-és Felnôttképzés, Vol. 4, No. 1, 53-65.

Szabolcsi, F. (1996) A szervezeti kultúra sajátosságai az iskolában [Organisational culture features in schools]. Iskolakultúra, Vol. 6, No. 5, 85-90. 